African Crop Science Journal by African Crop Science Society is licensed under a Creative Commons Attribution 3.0 Uganda License. Based on a work at www.ajol.info/ and www.bioline.org.br/cs DOI: http://dx.doi.org/10.4314/acsj.v26i1.10

\title{
STATUS AND UTILISATION OF Moringa oleifera Lam: A REVIEW
}

\author{
K. GANDJI ${ }^{1}$, F.J. CHADARE ${ }^{2}$, R. IDOHOU ${ }^{1}$, V.K. SALAKO ${ }^{1}$, A.E. ASSOGBADJO ${ }^{1,3}$ \\ and R.L. GLÈLÈ KAKAÏ ${ }^{1}$
}

${ }^{1}$ Laboratoire de Biomathématiques et d'Estimations Forestières (LABEF), Faculté des Sciences

Agronomiques, Université d'Abomey-Calavi, 04 BP 1525, Cotonou, République du Bénin

${ }^{2}$ School of Sciences and Techniques for Preservation and Processing of Agricultural products, University of Agriculture of Kétou, BP 114, Sakété, Republic of Benin

${ }^{3}$ Laboratoire d'Ecologie Appliquée (LEA), Faculté des Sciences Agronomiques, Université d'Abomey-Calavi, 01 BP 526, Cotonou, République du Bénin

*Corresponding author: gkisito@gmail.com

(Received 28 May, 2017; accepted 12 February, 2018)

\begin{abstract}
Moringa oleifera (Moringaceae) is a medium-size agroforestry tree that originated from south Asia, but has become naturalised in many countries globally. Moringa oleifera has gained importance due to its multipurpose uses and good adaptability to both humid and dry climates. Almost all parts of the plant are used. The species is considered as a neglected and underutilised as its potential is still not well economically known and valued. This review presents the status and factors responsible for underutilisation of this, otherwise important crop as a basis for formulation of viable development strategies of knowledge on taxonomy, distribution, diverse utilisations, nutritional value, socioeconomic importance, morphological and genetic diversity, domestication, propagation and management of $M$. oleifera. Knowledge gaps, and research and development avenues are suggested and discussed for improved valorisation. To that purpose, articles were searched in Google Scholar, Web of Science and BioMed Central database with relevant keywords on M. oleifera. All the articles found, including reviews and peer-reviewed articles were critically read and analysed for inclusion in this review. Findings revealed that the species is one of the most studied and used species with various uses stretching from food and medicinal uses to water purification, biopesticide and production of biodiesel. Findings also highlight high morphological and genetic diversity of the species, which may become a resource for the conservation and the selection of germplasm. However, many aspects of the species are still waiting for further research.
\end{abstract}

Key Words: Domestication, economy, genetic resources, Moringa oleifera, nutrition value

\section{RESUME}

Moringa oleifera (Moringaceae) est un arbre de taille moyenne originaire du sud de l'Asie, mais naturalisé dans de nombreux pays d'Afrique, d'Asie, d'Amérique et d'Australie. M. oleifera jouit d'une grande importance en raison de ses multiples usages et de sa bonne adaptabilité aux climats humides et secs. Les feuilles du Moringa sont parmi les légumes à feuilles les plus promus pour assurer la sécurité alimentaire et nutritionnelle des mères et des nourrissons dans les pays en développement. Presque toutes les parties de la plante sont utilisées en médecine. Jusqu'à présent, l'espèce est considérée comme négligée et sous-utilisée car son potentiel n'est toujours pas bien valorisé. Cet article résume l'état actuel des connaissances sur la taxonomie, la distribution, les utilisations diverses, la valeur nutritionnelle, l'importance socioéconomique, la diversité morphologique et génétique, la domestication, la propagation et la gestion de $M$. oleifera. Les gaps en termes de connaissances sur l'espèce ont 
été identifiées et des axes de recherche-développement ont été proposés et discutés pour améliorer sa valorisation. A cet effet, des articles ont été recherchés dans les bases de données Google Scholar, Web of Science et BioMed Central avec des mots-clés pertinents sur l'espèce. Tous les articles trouvés, y compris les revues et les articles évalués, ont été lus et analysés de manière critique pour leur inclusion dans cet article. Les résultats ont révélé que le Moringa est l'une des espèces les plus étudiées et utilisées au monde avec de multiples usages allant de l'alimentation et la médecine à la purification de l'eau, au biopesticide and à la production de biodiesel. Les résultats ont également révélé une grande variabilité morphologique et génétique de l'espèce, qui peut être une ressource pour la conservation et l'amélioration génétique de l'espèce. Cependant, beaucoup d'autres aspects de l'espèce nécessitent encore des investigations.

Mots Clés: Domestication, économie, ressources génétiques, Moringa oleifera, valeur nutritionnelle

\section{INTRODUCTION}

Moringa oleifera Lam. is the most widely cultivated species of the tropical flowering plant family Moringaceae containing thirteen diverse species (Shahzad et al., 2013). Moringa oleifera is indigenous to south Asia, where it grows in the Himalayan foothills from North-Eastern Pakistan to North-Western Bengal, India (Sharma et al., 2011). The species was introduced and became naturalised in other parts of the world including East and West Africa (Paliwal et al., 2011). It has a great potential to serve as a high-value food crop, medicinal products, as well as fodder for animals, particularly in developing countries (Shahzad et al., 2013).

The key uses of Moringa include human nutrition (leaves, seeds, flowers), alley cropping (biomass production for biodiesel and fertilising), animal forage (leaves and treated seepod-cake), biogas (from leaves), domestic cleaning agent (crushed leaves), blue dye (wood), fencing (living trees), fertiliser (seed-cake), foliar nutrient (juice expressed from the leaves), green manure (from leaves) (Fuglie, 1999; Adebayo et al., 2011; Popoola and Obembe, 2013; Leone et al., 2015). The species is also mainly used as gum (from tree trunks), honey and sugar cane juice-clarifier (powdered seeds), honey (flower nectar), medicine (all plant parts), ornamental plantings, biopesticide (soil incorporation of leaves to prevent seedling damping off), pulp (wood), rope (bark), tannin for tanning hides (bark and gum), water purification (powdered seeds) (Fuglie, 1999; Adebayo et al., 2011; Popoola and Obembe, 2013; Leone et al., 2015). Moringa oleifera is the cheapest and credible alternative to not only providing good nutrition, but also to cure and prevent a lot of diseases (Paliwal et al., 2011). Actually, the great interest in M. oleifera is related to its multipurpose uses and its ability to guarantee a good yield, where other crops cannot, in countries where people are mostly at risk of suffering from nutritional deficiencies (Leone et al., 2015). Indeed, its cultivation is localised in developing countries where different parts of the plant are utilised.

Some international initiatives such as the Moringa Fund, Trees for Life, Global Moringa Network, Moringa initiative, and Moringa News have been established to improve the production, uses especially for human nutrition, and to develop the marketing process and value addition. In Benin, The Hunger Project (an international NGO) promotes the species during its campaign for health and nutrition improvement. In many countries (e.g. Ghana, Benin, etc.) there is a National Association of Moringa which aims to organise people, including producers, consumers, processors and researchers to speak on a common platform on issues of Moringa in order to influence policy on promotions, production, consumption and marketing of the products. There is increasing number of literature reviews on the species of which one of the best and recent is performed by Leone et al. (2015) and has addressed cultivation, genetic, ethnopharmacology, phytochemistry and pharmacology of the species. 
Despite the great economic importance, $M$. oleifera is still not well exploited and hence considered as underutilised (Pandey et al., 2011). The present review aims at understanding the status and factors responsible for underutilisation of Moringa in West Africa.

\section{METHODOLOGY}

This literature review was entirely based on online published materials ranging from the year 1970 to 2017. Google Scholar, Web of Science and BioMed Central were searched as literature database with subsections: taxonomy, conservation biology, biodiversity, breeding, ethnobotany, nutritional values, pharmacology, socioeconomy, cultivation practices and domestication. The search was conducted using $M$. oleifera as a keyword within the title of the article. Articles dealing with species other than oleifera were also included. All the searched articles, including reviews, and peer-reviewed articles presenting results of experimental studies, in animals or humans, on $M$. oleifera were analysed and vital outputs included in this review. The analysis focused on the current state of knowledge on taxonomy, distribution, diverse utilisations, nutritional value, socioeconomic importance, morphological and genetic diversity, domestication, propagation and management of the species. Of the 188 articles found, 85 have been considered for this review.

\section{TAXONOMY AND DISTRIBUTION}

Moringa oleifera belongs to the family Moringaceae, order Capparales, class Magnoliopsida and division Magnoliophyta. The family includes other 12 species of shrubs and trees (Verdcourt, 1985; Olson, 2002). The 13 species of the genus Moringa (Table 1) are indigenous to Arabia, Africa and Asia (Olson, 2002). Among all these species, M. oleifera (hereafter referred to as Moringa) has so far become the most used and studied (Leone $e t$ al., 2015). Moringa oleifera was utilised by the ancient Romans, Greeks and Egyptians, and is now widely cultivated throughout the tropical and subtropical regions of the world (Fahey, 2005).

Moringa has been widely naturalised in other tropical regions of the world (Fig. 1). It has been reported from large parts of southern and eastern Asia (Verdcourt, 1985; Lu and Olson, 2001). It has been also widely naturalised in Africa mainly in sub-Saharan Africa (Verdcourt, 1985; GBIF, 2007). In

TABLE 1. Species of genus Moringa and their native countries/regions

\begin{tabular}{ll}
\hline Species & Native countries/regions \\
\hline Moringa arborea Verdc. & Kenya \\
Moringa rivae Chiov. & Kenya and Ethiopia \\
Moringa stenopetala Cufod. & Kenya and Ethiopia \\
Moringa borziana Mattei, & Kenya and Somalia \\
Moringa longituba Engl. & Kenya and Somalia \\
Moringa pygmaea Verdc. & Somalia \\
Moringa ruspoliana Engl. & Kenya, Ethiopia and Somalia \\
Moringa ovalifolia Dinter and A. Berger & Namibia and Angola \\
Moringa drouhardii Jum., & Madagascar \\
Moringa hildebrandtii Engl. & Madagascar \\
Moringa peregrina Forssk. & Arabia, Red sea and Dead sea \\
Moringa concanensis Dalzell and A. Gibson & Sub-Himalayan tracts of India subcontinent \\
Moringa oleifera Lam. & Sub-Himalayan tracts of India subcontinent \\
\hline
\end{tabular}

Source: Olson, 2002 


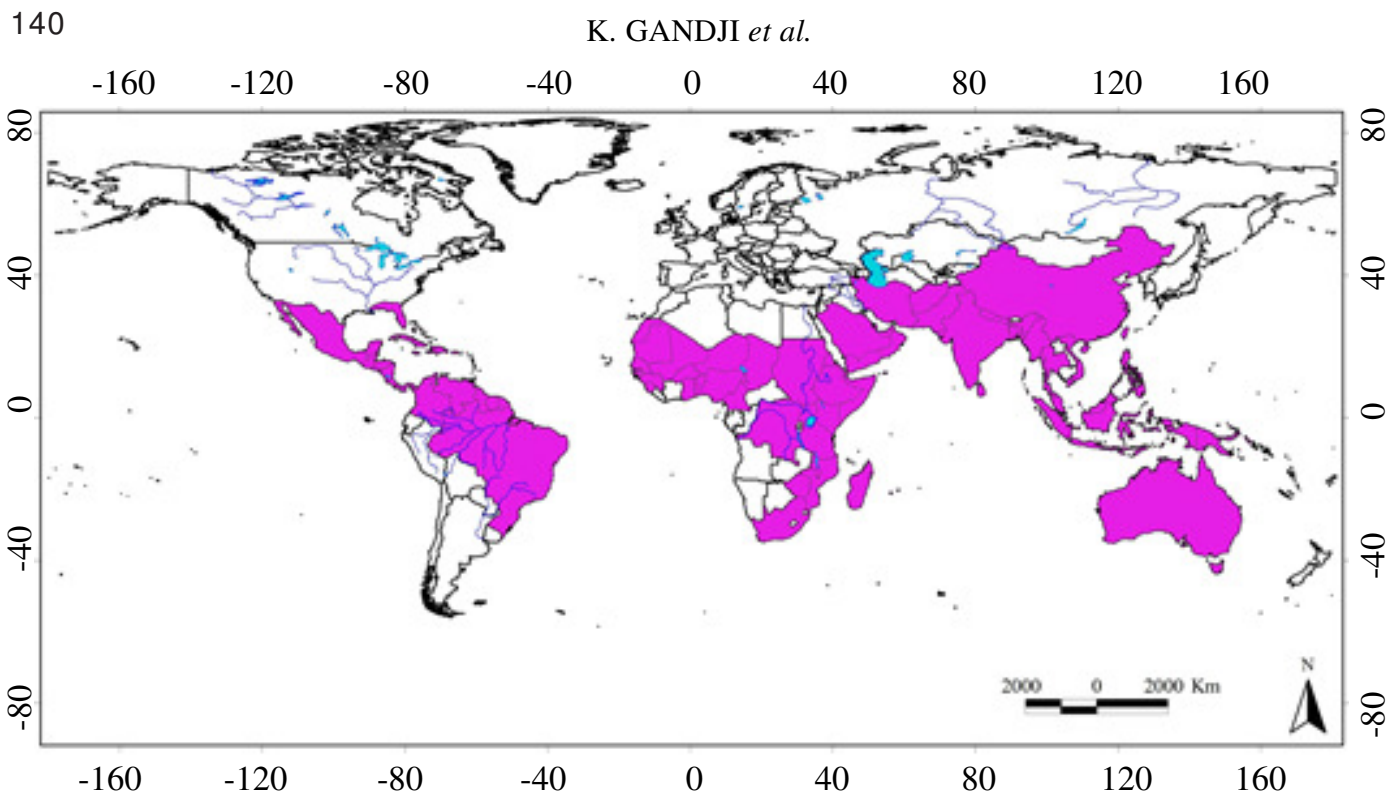

Figure 1. Countries where Moringa oleifera has been recorded as either native or naturalised Adapted from Navie and Csurhes (2010).

tropical America, Moringa is naturalised in both north and South America (ICRAF, 2001; Liogier and Martorell, 2000). Moringa is also naturalised on several Pacific islands (Hancock and Henderson, 1988; ICRAF, 2001; PIER, 2007). With such naturalisation in so diverse regions, Moringa can be considered a highly plastic species.

With such naturalisation in so diverse regions, Moringa can be considered a highly plastic species that adapts well to hot, semiarid regions with as little as $500 \mathrm{~mm}$ annual rainfall (Bosch, 2004; Ebert, 2014). Once it has been established, its strong antioxidant system helps coping with moderate saline conditions, experiencing only a mild reduction in its mineral quality (Nouman et al., 2012). In general, Moringa grows best in lowland cultivation, but it also adapts to altitudes above $2000 \mathrm{~m}$ (Ebert, 2014). Slightly alkaline clay and sandy loam soils are considered the best media for Moringa due to their good drainage (Ramchandran et al., 1980, Abdul, 2007, Nouman et al., 2014). Moringa tolerates a wide range of soil types and $\mathrm{pH}$ (4.5-9) but prefers well-drained soils in the neutral $\mathrm{pH}$ range (Paliwal and Sharma, 2011).

\section{SIGNIFICANCE OF MORINGA}

Moringa oleifera is one of the world's mostly used plants (Palada and Chang, 2003). All parts of the species are traditionally used for different purposes, but leaves are generally the most used (Popoola and Obembe, 2013; Sivasankari et al., 2014). Seven use categories of $M$. oleifera, namely medicine, food, fodder, fencing, firewood, coagulant and gum have been identified (Popoola and Obembe, 2013; Agoyi et al., 2014; Sivasankari et al., 2014). The species is mostly used as a traditional medicine and food (Popoola and Obembe, 2013; Agoyi et al., 2014; Sivasankari et al., 2014).

Food uses and nutritional value. Each part of the Moringa tree (fruits, seeds, leaves, flowers, bark and roots) is associated with the presence of at least one, or in most number of benefits (Zaku et al., 2015). Leaves are rich in protein, mineral, beta-carotene and antioxidant compounds, which are often deficient among the diets of developing countries (Leone et al., 2015). Through research, the Moringa parts were found to 
contain many essential nutrients (Fahey, 2005; Kasolo et al., 2010). Moringa leaves contain high levels of vitamin $\mathrm{C}$, calcium and potassium, as well as protein (Table 2) (Zaku et al., 2015). Due to the presence of several kinds of antioxidant compounds such as flavonoids, ascorbic acid, carotenoids, and phenolics, Moringa leaves are able to extend the shelf life of food containing fats (Dillard and German, 2000; Siddhuraju and Becker, 2003). In addition, Moringa was found to have a group of unique compounds containing sugar

TABLE 2. Chemical composition of dried leaf powder of Moringa per $100 \mathrm{~g}$ of edible portion of leaves

\begin{tabular}{|c|c|}
\hline Nutritional value per $100 \mathrm{~g}$ & Values \\
\hline Moisture (\%) & 7.5 \\
\hline Calories (Kcal) & 205 \\
\hline Protein $(g)$ & 27.1 \\
\hline Fat $(\mathrm{g})$ & 2.3 \\
\hline Carbohydrate (g) & 38.2 \\
\hline Fiber $(g)$ & 19.2 \\
\hline \multicolumn{2}{|l|}{ Trace minerals } \\
\hline Calcium (mg) & 2,003 \\
\hline Magnesium (mg) & 368 \\
\hline Phosphorus (mg) & 204 \\
\hline Potassium (mg) & 1,324 \\
\hline Iron $(\mathrm{mg})$ & 28.2 \\
\hline Sodium (mg) & 870 \\
\hline \multicolumn{2}{|l|}{ Vitamins } \\
\hline Vitamin A-Beta Carotene (mg) & 16.3 \\
\hline Vitamin $B_{1}-$ thiamin $(m g)$ & 2.64 \\
\hline Vitamin $B_{2-}$ riboflavin $(\mathrm{mg})$ & 20.5 \\
\hline Vitamin $\mathrm{B}_{3}^{2-}$ - nicotinic acid (mg) & 8.2 \\
\hline Vitamin C ascorbic acid (mg) & 17.3 \\
\hline Vitamin E tocopherol acetate $\mathrm{mg}$ ) & 113 \\
\hline \multicolumn{2}{|l|}{ Amino acids } \\
\hline Arginine $\left(\mathrm{g} 16^{-1} \mathrm{~g} \mathrm{~N}\right)$ & 1.33 \\
\hline 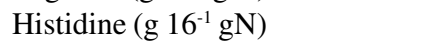 & 0.61 \\
\hline Lysine $\left(\mathrm{g} 16^{-1} \mathrm{gN}\right)$ & 1.32 \\
\hline Tryptophan $\left(\mathrm{g} 16^{-1} \mathrm{gN}\right)$ & 0.43 \\
\hline Phenylanaline (g $\left.16^{-1} \mathrm{gN}\right)$ & 1.39 \\
\hline 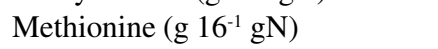 & 0.35 \\
\hline Threonine $\left(\mathrm{g} 16^{-1} \mathrm{gN}\right)$ & 1.19 \\
\hline Leucine $\left(\mathrm{g} 16^{-1} \mathrm{gN}\right)$ & 1.95 \\
\hline Isoleucine $\left(\mathrm{g} 16^{-1} \mathrm{gN}\right)$ & 0.83 \\
\hline Valine $\left(\mathrm{g} 16^{-1} \mathrm{gN}\right)$ & 1.06 \\
\hline \multicolumn{2}{|l|}{ Other constituents } \\
\hline Oxalic acid (mg) & 1.6 \\
\hline
\end{tabular}

Source: Jahn (1996); Zaku et al. (2015) and rhamnose, which are uncommon sugar modified glucosinolates (Fahey et al., 2001; Fahey, 2005). These compounds were reported to demonstrate certain chemopreventive activity, by inducing apoptosis (Brunelli et al., 2010). The species has a particularly high level of oleic acid $(70 \%)$, making it a great moisturiser, as well as a potentially healthy source of fat in the diet (other vegetable oils normally contain only about $40 \%$ oleic acid). Moringa leaves are added to food preparations as integrators of the diet (Leone et al., 2015). Moringa leaves are eaten as salad, vegetable soup for human nutrition (Popoola and Obembe, 2013) and as forage for animal feed (Nouman et al., 2014). Seeds are roasted and eaten like groundnut (Popoola and Obembe, 2013). In India, Moringa leaves have been processed into an innovative drink named Zija (Ansari and Kumar, 2012). Moringa is also used and valorised through food fortification. For instance, in Nigeria, it is used to fortify food formulations of corn, soy and peanut (Shiriki et al., 2015); and as food fortificant in amala (stiff dough), ogi (maize gruel), bread, biscuits, yoghurt, cheese and in making soups (Oyeyinka and Oyeyinka, 2016). However, validation works are needed to substantiate food fortification potential of the species. In addition, limited studies have assessed the shelf stability of the fortiûed samples (Oyeyinka and Oyeyinka, 2016).

Medicinal uses. Moringa is considered rich with several medicinal properties, as all the parts have been reportedly singly or with other plants for treating diverse illnesses and diseases (Fuglie, 1999; Pamok et al., 2011). In traditional medicine, the leaves are used to treat ailments including malaria, typhoid fever, parasitic diseases, arthritis, swellings, cuts, diseases of the skin, genito-urinary ailments, hypertension and diabetes (Leone et al., 2015). They are also used to elicit lactation and boost the immune system (to treat HIV/AIDS related symptoms) (Anwar et al., 2007; Popoola and Obembe, 2013; Sivasankari et al., 2014), as well as cardiac stimulants and contraceptive 
remedy. For the treatment of these ailments, one can directly consume either raw and dried leaves, or the extract of an aqueous infusion (Leone et al., 2015). The uses of the species leaves in the treatment of HIV infections and cancer have been reported by local people in Nigeria (Popoola and Obembe, 2013). There are few published works on these specific uses because of the lacking sufficient scientific based information.

Barks are boiled in water and soaked in alcohol to obtain decoction and extract, respectively, that can be used to treat stomach ailments (ease stomach pain, ulcer and aiding digestion), poor vision, joint pain, diabetes, anemia and hypertension (Abe and Ohtani, 2013; Popoola and Obembe, 2013), toothache, hemorrhoids, uterine disorder (Popoola and Obembe, 2013; Yabesh et al., 2014). In a wellknown practice to local people in Nigeria, Moringa seeds are used to sediment impurities of water (Popoola and Obembe, 2013). Roots are soaked in water or alcohol and boiled to obtain decoction and extract as remedies for toothache, as anthelmintic and antiparalytic (Anwar et al., 2007; Popoola and Obembe, 2013; Sivasankari et al., 2014) drugs and as sex stimulant. Finally, flowers are used to produce aphrodisiac substances and to treat inflammations, muscle diseases, hysteria, tumours and enlargement of the spleen (Anwar et al., 2007; Yabesh et al., 2014). The activities against the above diseases were confirmed in several screening tests and ethnopharmacology studies (Pamok et al., 2011; Abe and Ohtani, 2013; Popoola and Obembe, 2013; Sivasankari et al., 2014; Yabesh et al., 2014).

Other uses. Besides being consumed by humans for food and health purposes, Moringa is used as animal fodder (Sanchez et al., 2006; Nouman et al., 2013, 2014) and as a natural coagulant of turbid water (Suarez et al., 2003). Actually, Moringa seed powder can be used for water purification, replacing dangerous and expensive chemicals such as aluminium sulfate
(Popoola and Obembe, 2013). The species is used as a natural plant growth enhancer because its leaves are rich in zeatin, a plant hormone, which belongs to the cytokinin group (Leone et al., 2015). Leaf extracts can stimulate plant growth and increase crop yield. For instance, application of Moringa leaf extract at 2 weeks after emergence and at every 2 weeks thereafter, significantly increased growth performances of maize in terms of plant height, shoot length, fresh and dry weight of shoots, number of grains $\mathrm{cob}^{-1}, 100$-grain weight, and grain weight plant ${ }^{-1}$ (Biswas et al., 2016).

Therefore, the species would be a very useful species for the improvement of food security.

The suitability of Moringa seed oil as biodiesel feed source has been proved, and oil could be used as pure biodiesel or petro-diesel mixture on engine (Da Silva et al., 2010). Moringa oil has also excellent characteristics, making it a highly valued ingredient in a variety of applications, ranging from vegetable food oil to use in cosmetic products and other industrial applications such as lubricant for fine machinery (SFA, 2015).

There are lots of opportunities for Moringa production as the species has been observed to be well suited to all kinds of soils and wide range of environment, especially tolerant to poor soils of arid and semi-arid regions (Navie and Csurhes, 2010; Padulosi et al., 2011). Besides its nutritional and medicinal value and multiple uses, Moringa improves livelihood security and crop diversification (Gadzirayi et al., 2013), and is of considerable interest for future adaptation of agriculture to climate change (Padulosi et al., 2011). In Niger, Tabbo and Amadou (2017) found that the introduction of $M$. oleifera into agricultural systems was among the most important adaptation strategies to climate change for farmers among rural households. Actually, the species can be used as soil improver as green manure and seed cake as fertiliser and also provides important ecosystems services (Mridha, 2015). These 
ecosystems services includes reforestation, in alley cropping, erosion control, boundary, barrier and support (Mridha, 2015).

The anti-erosive potential of the species has demonstrated by Avakoudjo et al. (2013); while Noulékoun et al. (2017) have demonstrated its suitability for the afforestation of degraded croplands. Moreover, the rate of Moringa tree to absorb carbon dioxide $\left(\mathrm{CO}_{2}\right)$ is fifty times (50x) higher when compared to the Japanese cedar tree; and also twenty times (20x) higher than that of general vegetation (Villafuerte et al., 2009; Hernandez et al., 2015; Potadar and Patil, 2017). As such, integration of the species in agroforestry systems will mitigate the impacts of climate change (Kumar et al., 2017).

As the nutritional values of $M$. oleifera significantly contribute to reduced food insecurity, the maintenance of these value under climatic change become a great challenge which need to be fixed. Also, further studies are needed to assess the carbon sequestration potential of the species in many geographical zones and under different ecological conditions in the context of climate change.

Socioeconomic importance of Moringa. The relative ease with which Moringa is propagated through both non-clonal and clonal means, and its low demand for soil nutrients and water makes its production and management easy (Paliwal et al., 2011). Introduction of this plant into a farm which has a diverse environment can be beneficial for both the owner of the farm and the surrounding ecosystems (Fuglie, 1999). The great socioeconomic importance of Moringa has been demonstrated by Torimiro et al. (2009), Madi et al. (2012), Animashaun and Toye (2013), and Azeez et al. (2013). For instance, in western Nigeria, the analysis of the profitability of a leaf-based Moringa production indicated an average net profit of $59.81 \%$ per hectare and per year from the sale of leaves (Animashaun and Toye, 2013).
Otherwise, the majority $(51.66 \%)$ of sellersretailers believe that the sale of Moringa leaves is profitable and even $26.66 \%$ of them claim it is twice as profitable as other leafy vegetables in northern Cameroon (Madi et al., 2012).

Currently, the international market for Moringa is not sufficiently developed to be qualified as a commodity on the global market; hence trade statistics for Moringa products are only available in an aggregated form (SFA, 2015). The global market for Moringa products is considered substantial, however, with current estimates of over US $\$ 4$ billion a year worldwide (CJP, 2014). While Moringa is used for a wide variety of purposes, two Moringa products in particular stand out in terms of their commercial potential: Moringa leaf powder and Moringa oil as an ingredient for cosmetic products. Over the past few years, an increasingly large variety of Moringa products has spread into many markets, and are now available on most health food websites and in many health stores worldwide (SFA, 2015). Moringa leaf powder can be sold simply or in containers or in plastic bags that prevent moisture absorption. Moringa leaves powder is also sold in the form of tea or mixed with chocolate.

The commercialisation of Moringa products is still very informal and makes it difficult to get reliable information of production volumes and prices (SFA, 2015). Therefore, to effectively exploit the existing market potential, commercialisation should become structured and formalised. In addition, there is need to develop value chains for the species. Actually, the value chain for Moringa product, if properly developed, offers considerable investment opportunities, and potential job creation, foreign exchange earnings and export diversification (Animashaun and Toye, 2013). However, growers need to be able to ensure compliance with international regulation and standards, be able to offer high quality and continuous supply. 


\section{MORPHOLOGICAL CHARACTERISTICS, GENETIC DIVERSITY AND DOMESTICATION}

Morphological characteristics. The variation in morphological traits of Moringa has been investigated worldwide through characterisation of morphological traits (Table 3 ). The great variability is probably due to various ecological conditions in which the species is grown and the various management practices. Actually, the significant variation in morphological trait found in Southern Benin may be due to ecological conditions, time of leaf harvesting, harvesting frequency and plant density (Agoyi et al., 2015). However, to what extent variations in ecological conditions and farmers' management practices influence morphological traits of the plant parts of $M$. oleifera, have received little attention. Yet, this has implications for genetic improvement and conservation, and development of domestication strategies. Actually, unequal traditional knowledge, unequal valuation, and ethnic differentiation are strong sources of genetic diversity that can help determine diversities available in the morphology, chemical components, taste, anatomy and other characters of the species (Popoola and Obembe, 2013).

Genetic diversity. Cytological studies revealed that Moringa has $2 \mathrm{c}$ genome size of $1.2 \mathrm{pg}$ (Ohri and Kumar, 1986), and it is a true diploid, with $2 \mathrm{n}=28$ (Ramachandran et $a l ., 1980)$. Moringa is a cross-pollinated tree; hence high heterogeneity in form and yield is expected (Leone et al., 2015). Through investigations on variability in the species variability was reported in flowering time (from annual type to perennial type) (Raja et al., 2013), tree nature (from deciduous to evergreen), tree shape (from semi spread to upright), and resistance to hairy caterpillar (Mgendi et al., 2011; Raja et al., 2013). Although Moringa shows diversification in many characters and high morphological variability (Ganesan et al., 2014; Popoola et

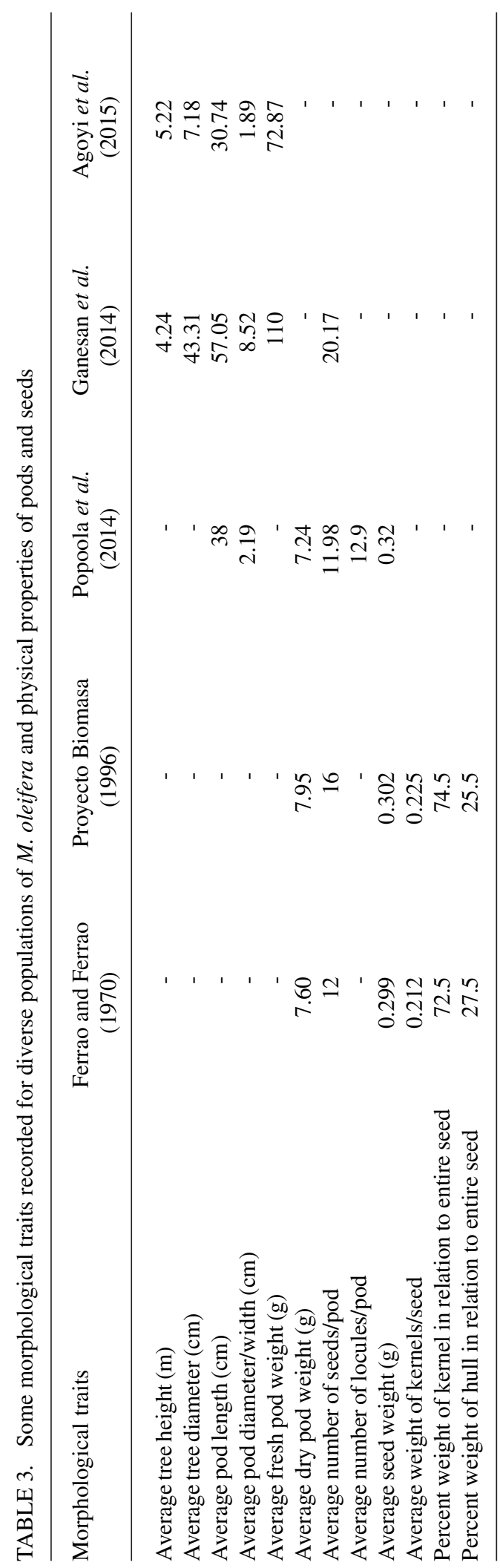


al., 2014; Agoyi et al., 2015), which may become a resource for its improvement, the major factors that limit productivity are the absence of elite varieties adapted to local conditions and the use of seeds obtained through open pollination from plants in the planted area (Leone et al., 2015). Moringa oleifera being indigenous to India, many ecotypes exist with various morphological traits. Several varieties have been developed and are available in India. For instance, to improve pod production, two varieties (PKM1; PKM2) have been developed at the Horti Nursery Networks, Tamil Nadu in India. Usually those varieties are grown as annual; after two harvests the tree is dragged out and new seedlings are planted (Saint Sauveur, 2001).

A recent morphological study of three hundreds genotypes belonging to twelve populations of Moringa in India, revealed that yellow, white and pinkish are the main colours of the species' flowers (Ganesan et al., 2014). Many research centres focusing on M. oleifera improvement have been established across the world; namely AVDRC (Taiwan), rural development initiative (Zambia), Moringa Philippines foundation (Philippines) and Moringa community (Zambia). In spite of the great variability of Moringa, no institution has a germplasm bank or database with either cultivated or spontaneous accessions (Leone et al., 2015). It is recommended that the divergence between genetic variability inherent to the species and the poor variability reflected in germplasm banks be fixed since it represents an obstacle for the progress of breeding programmes.

The genetic approach and its potential application in breeding programmes for Moringa are just at the infant stage (Leone $e t$ al., 2015). Thus far, there is limited knowledge of available genetic diversity present in Moringa (Shahzad et al., 2013). However, substantial variation in quantitatively inherited traits has been documented in natural populations of Moringa in India (Ramachandran et al., 1980). Moreover, limited studies have been conducted using DNAbased markers to identify and assess diversity among various genotypes of $M$. oleifera (Shahzad et al., 2013). Muluvi et al. (1999) and Ulloa (2005) used ampliûed fragment length polymorphism (AFLPs) to investigate M. oleifera populations present in Kenya, revealing signiûcant differences between regions and populations. Random ampliûed polymorphic DNA (RAPD) were used to investigate cultivated and non-cultivated populations of M. oleifera in Tanzania (Mgendi et al., 2010), different accessions in Nigeria (Abubakar et al., 2011), accessions present in Brazil (Da Silva et al., 2012), commercially grown varieties in India (Saini et al., 2013), and new genotype developed in different countries (Thailand, USA, India and Malaysia, Tanzania, Taiwan) (Rufai et al., 2013). These studies provided evidences of a high level of genetic diversity in natural population compared to the cultivated ones (Leone et al., 2015), concluding that conservation strategies should be adopted (Shahzad et al., 2013).

Wu et al. (2010) have developed 20 microsatellite or simple sequence repeat (SSR) markers for Moringa that serve as useful markers for pursuing additional genetic diversity studies. The first successful estimates of genetic diversity and population structure of the species were obtained with Simple Sequence Repeat (SSR) in 2013 by Shahazad et al. (2013). These authors evaluated accessions collected in different locations of Pakistan and accessions from different countries (India, Tanzania, Senegal, Mozambique, Zimbabwe, Florida, Mexico, Haiti, and Belize) obtained from Educational Concerns for Hunger Organisation (ECHO). They found high genetic diversity in wild Pakistan accessions; whereas low genetic diversity in ECHO accessions. Later on investigation on twelve Indian populations, from northern and southern regions of India, was performed through simple sequence repeat (SSR) together with morphological markers (Ganesan et al., 2014). In this study too, individuals from various geographical areas 
were not significantly different genetically, while a large variability exist in Indian populations. More SSR were identified in 2014 thanks to expressed sequence tags (EST) examination involving several plant species (Haq et al., 2014) and not utilised so far in Moringa genetic investigation (Leone et al., 2015). Today, next generation sequencing (NGS) (Davey et al., 2011) is an approachable tool to discovery genome-wide genetic markers. Thanks to NGS a saturated genetic map could be obtained within reasonable cost and time, in turn interesting characters could be identified and exploited in breeding programmes (Leone et al., 2015). Although all the reported findings are valuables and essentials for the conservation, selection and collection of M. oleifera seeds, more scientific based information are needed in order to develop improved cultivation and management practices of the species.

Domestication trends. Analysis of diversity distribution pattern, utilisation based socioeconomic study and dependence of population on local useful genetic resources throw light on folk domestication trends in regions with rich diversity (Arora, 1987; Pandey et al., 2011). In areas of natural distribution of Moringa (the west and central Himalaya and the foothills and parts of central India), the species exhibits rich variability in fruit types in wild/semi-domesticated populations, with minimal recorded use of plant (Samant and Dhar, 1997; Tiwari et al., 2010). This trend is obviously more observed in areas where the species have been naturalised. For instance, in Southern Benin, significant differences were observed in pods length and diameter; while the species is not widely used and leaves are the most plant part used (Agoyi et al., 2015). Similar trends were recorded in India for the use of edible oil (Vishnu, 1981), vegetable and pickled fruits (Jain, 1981; Sawian et al., 2007) and edible leaves, ûowers, fruits (Bhargava, 1981). However, frequent cultivation and wider use of Moringa as vegetable crop and as multipurpose species suggests a long history of domestication (Pandey et al., 2011).

\section{PROPAGATION, INITIAL GROWTH AND MANAGEMENT}

The bisexual flowers of Moringa are highly cross-pollinated, and pollination is mainly facilitated by animals (i.e. the flowers are zoophilous). For example, bees (Xylocopa spp.) and sunbirds (Nectaria spp.) have been observed to be active and reliable pollinators in many parts of the world (ICRAF, 2001). Moringa oleifera does not seem to require any specific pollinators, as it readily produces viable seeds. There is little information available regarding the dispersal mechanisms of $M$. oleifera; however, much can be determined from its seed morphology and the locations in which it tends to become naturalised (DuPuy, 1993; Navie and Csurhes, 2010; Okorocha et al., 2015). Although the seeds are relatively large, they are strongly winged. This may allow them to be spread short distances from the parent tree by wind (DuPuy, 1993; Navie and Csurhes, 2010; Okorocha et al., 2015).

Moringa oleifera is propagated in two main ways; by sowing and by cutting. The preference for a propagation mode varies among countries. Traditionally, in Sudan seeds are preferred; while vegetative propagation is common in India, Indonesia and in some areas of West Africa (Palada, 1996; Leone et al., 2015). To lift the dormancy of the seeds, they are soaked in water for 12 hours of time. Seeds germinate within two weeks, at a maximum of $2 \mathrm{~cm}$ depth. When sowing is planned in nursery, the seedlings can be transplanted when they reach about $30 \mathrm{~cm}$ (3-6 weeks after germination) (Ojiako et al., 2011). Under ideal storage conditions $\left(3{ }^{\circ} \mathrm{C}, 5-8 \%\right.$ moisture), the germination rate is approximately $80-90 \%$ (Leone et al. 2015). However, the viability decreases when seeds remain at ambient temperature and high relative humidity; their germination rate dropping to $7.5 \%$ after three months (Morton, 1991; Roloff et al., 2009). 
Cutting is preferred when seed availability is scarce and/or when labour is not a limiting factor (Leone et al., 2015). Plants raised from seeds produce fruits of poorer quality (Ramachandran et al., 1980). Animashaun (2013) argues that trees grown from seeds develop longer roots (an advantage for stabilisation and access to water) compared to those grown from cuttings that have much shorter roots. Since the tree vigorously resprouts after cutting, pruning or pollarding are usually practiced to enhance lateral branching and give the tree a bush shape in order to facilitate the harvest (Leone et al., 2015). Nevertheless, there are no figures to support those practices.

For the intensive production of $M$. oleifera leaves, plantation can be designed with spacing ranging from $10 \mathrm{~cm} \times 10 \mathrm{~cm}$ to $20 \mathrm{~cm} \times 20$ $\mathrm{cm}$; harvest interval between 35 to 45 days; while irrigation and fertilisation are needed (Leone et al., 2015). The semi-intensive production of leaves can be made with spacing of $50 \mathrm{~cm} \mathrm{x} 100 \mathrm{~cm}$, harvest interval between 50 to 60 days; while irrigation and fertilisation are suggested. Plantations for leaf production can also be integrated in agroforestry systems with spacing distance of 2-4 $\mathrm{m}$ between rows, harvest interval around 60 days, fertilisation and irrigation are not necessary (Leone et al., 2015). Gadzirayi et al. (2013) recommended in Zimbabwe $20 \mathrm{~cm}$ x $20 \mathrm{~cm}$ as plant spacing and 60 and 75 days as harvest intervals according to provenances.

In Ghana, the optimum plant spacing is 5 $\mathrm{cm} \times 15 \mathrm{~cm}$ with 35 to 40 days as optimum harvest intervals (Newton et al., 2006). In Nicaragua, $20 \mathrm{~cm} \times 20 \mathrm{~cm}$ and 75 days are optimum plant spacing and harvest intervals, respectively (Sanchez et al., 2006). This wide range of cutting frequencies (40-75 days) is likely due to differences in the climatic conditions in which the species is grown (Nouman et al., 2014).

Production decreases from intensive production to less dense spacing (agroforestry system), although a tremendous variability can be observed for a given spatial distribution and the same cultivation management. Moringa leaf's production varies according to planting densities and cutting frequencies (Table 4).

Fruits, referred to as pods, ripen at about three months after flowering and must be harvested as soon as possible. A single tree can produce 300 to 400 fruits per year within three years of planting; while a mature tree can produce up to 1000 fruits per year (HDRA, 2002). As noticed for leaves, the production of seed is also highly variable. As each fruit contains approximately 20 seeds, a mature tree can therefore produce about 20000 seeds per year (Navie and Csurhes, 2010).

A single seed weights on average is $0.3 \mathrm{~g}$ (Ayerza, 2011). Early flowering varieties produce pods in six months; while other varieties require more than one year (Leone $e t$ al., 2015). After pruning, branches develop new pods within 6 months (Paliwal et al., 2011). Regarding the cultivation systems, $M$. oleifera is cultivated around homesteads, or in association with other vegetables in home gardens, or in association with fruit trees in orchards (Gadzirayi et al., 2013).

The species is resistant to most pests and diseases, but outbreaks may occur under certain conditions (Palada and Chang, 2003). For example, diplodia root rot may appear in waterlogged soils, causing severe wilting and death of plants (Palada and Chang, 2003). Mite populations can increase during dry and cool weather. These pests induce yellowing of leaves, but plants usually recover during warm weather. Other insect pests include termites, aphids, leaf miners, whiteflies, and caterpillars (Palada and Chang, 2003). In Zimbabwe, farmers experienced problems with sap sucking insects (red spider mite and aphids), leaf eating insects (caterpillars) and termites (Gadzirayi et al., 2013). Chemical control of insect pests should be used only when severe infestations occur. Choose a pesticide that targets the specific pest causing the damage, and avoid pesticides that kill or inhibit the development of beneficial organisms (Palada 
TABLE 4. Some M. oleifera leaf production on various planting densities and cutting frequencies

\begin{tabular}{|c|c|c|c|c|c|}
\hline \multirow{2}{*}{$\begin{array}{l}\text { Fresh biomass }\left(\mathrm{kg} \mathrm{ha}^{-1}\right) \\
\left.\text { Planting densities (plants ha- }{ }^{-1}\right)\end{array}$} & \multicolumn{4}{|c|}{ Dry biomass $\left(\mathrm{kg} \mathrm{ha}^{-1}\right)$} & \multirow[t]{2}{*}{ References } \\
\hline & $1^{\text {st }}$ year & $2^{\text {nd }}$ year & $1^{\text {st }}$ year & $2^{\text {nd }}$ year & \\
\hline 95,000 & 19,600 & - & 3,330 & - & Foidl et al. (2001) \\
\hline 350,000 & 29,700 & - & 5,050 & - & \\
\hline 900,000 & 52,600 & - & 8,940 & - & \\
\hline $1,000,000$ & 78,000 & - & 13,260 & - & \\
\hline $4,000,000^{*}$ & 97,400 & - & 16,560 & - & \\
\hline $16,000,000^{*}$ & 25,900 & - & 44,030 & - & \\
\hline 250,000 & 80,200 & 41,100 & 17,600 & 7600 & Sanchez et al. ( 2006) \\
\hline 500,000 & 79,100 & 46,200 & 16,900 & 8100 & \\
\hline 750,000 & 88,000 & 36,100 & 18,900 & 6200 & \\
\hline \multicolumn{6}{|l|}{ Cutting frequency (days) } \\
\hline 45 & 71,400 & 26,700 & 13,500 & 4700 & Sanchez et al. ( 2006) \\
\hline 60 & 75,300 & 39,400 & 15,200 & 6800 & \\
\hline 75 & 100,700 & 54,700 & 24,700 & 10,400 & \\
\hline
\end{tabular}

*: Test plots with higher planting densities 
and Chang, 2003). They also recommended choosing pesticides that last only a few days. Many animals like cattle, sheep, pigs, and goats feed with Moringa seedlings, pods and leaves. It is recommended to protect Moringa seedlings from livestock by installing fence or by planting a hedge around the plot.

Gadzirayi et al. (2013) identified the following constraints in cultivating M. oleifera: lack of knowledge on efficient production practices, competition for land with other food crops, difficulty in the procurement of planting materials, shortage of water for irrigation during dry months, animal damage, low yield levels, theft, pests and diseases, and lack of markets. Regarding the lack of knowledge on efficient production practices, farmers lack efficient cultivation systems which make use of improved models. They have to abandon subsistence production to venture into monoculture of Moringa at very high tree densities on small pieces of land or they do it in various agroforestry patterns that give them better yields like in Niger and northern Nigeria (Gamatie, 2001; Saint Sauveur, 2001).

\section{KNOWLEDGE GAPS AND RESEARCH AVENUES}

The present review summarises the information available on the potential of $M$. oleifera in terms of cultivation, biodiversity and uses. However, many aspects of the species from the most convenient agricultural practices to its better use are still waiting for further research.

Utilisations. Due to the fact that the species is still neglected and underutilised, there is a true need to increase its level of use. This could be achieved not only through ethnobotanical assessment, food processing and nutrition work, but also through identification of factors which influence adoption of the species. The ethnobotanical assessment will highlight knowledge of local people on the uses of the species but also factors limiting it uses. The food processing and nutritional will identify ways to improve traditional use for a better nutritional health. Investigations on the drivers of the species use will improve understanding of factors limiting its adoption and provide ways forward to promote the species.

Production. According to knowledge highlighted by this review, there is also a need to increase the level of cultivation of the species. This could be firstly made through identification of the factors influencing the species cultivation. Considering the cultivation challenges, cultivation systems need to be explored. The spacing in planting $M$. oleifera trees must be designed to facilitate the relevant harvest and the management practices. Since literature reports about the good management practices of $M$. oleifera are scant, more practical trials are needed. For instance, there is not a consensus about the proper sowing densities and harvesting frequencies. Further studies have to assess optimum spacing and harvest intervals that comply with the different climates and production systems. Information about the production in other countries than India is scarce, so the production has to be estimated through experimentations.

So far, few studies have focused on Moringa cultivation system and this may explain why some important cultivation systems like fencing and agroforestry systems were not found in literature as cultivation system. Investigating the cultivation systems of Moringa are needed to understand how the species is cultivated, the species performance according to cultivation systems and factors determining the choice of a cultivation system. This way, constraints as gender associated with the species adoption at local level will be highlighted.

Breeding. Collection and characterisation of world accessions, both cultivated and natural, have to be prioritised in order to obtain a true understanding of the genetic diversity and structure of M. oleifera. This will help to have 
a reliable access to information about genetic materials to develop better Moringa varieties and technologies for farming practices. For the accessions evaluation, phenotypic characterisation is a priority to identify important plant traits. Studies are needed on breeding biology, genetic improvement and hybridisation, especially with the close relatives, identifying ecotypes for industrial value with higher percentage of seed oil, proteins, medicine and wide adaptability to agro-climate.

A collaborative network among National and International Research Centre, NGOs, farmers that already work on $M$. oleifera have to be set. Policy makers, research and extension institutions should formulate programs focusing on generating awareness among local communities and farmers.

Ecological services. The changing temperatures and wind patterns associated with climate change can affect precipitation factors, giving the species the ability to grow taller in some areas. Therefore, investigations on the potential impacts of climate change on the species growth are needed to efficiently design cultivation practices. Further studies are also needed to assess the carbon sequestration potential of the species under different ecological conditions taking into account the global warming.

Socio-economics and value addition. Temperature stress can affect the chemical composition of the species and therefore the nutritional value affecting negatively food security. As such, assessing the effects of temperature stress on the chemical composition of its leaves would allow to understand how climate change can affect its nutritional value. An analysis of sociocultural perceptions on the species would also provide further understanding of the behaviour of local people regarding the species. Considering the very important market value of $M$. oleifera, investigations are needed to assess the profitability of its marketing and to establish the value chain.

\section{CONCLUSION}

Moringa oleifera is one of the most studied and used species with various use categories stretching from food and medicinal uses to water purification, biopesticide and production of biodiesel. The species shows discrepancies in many features and high morphological and genetic diversity, which may become a resource for the conservation and the selection of germplasm. There is tendency of researches to associate phenotypical and molecular data in order to identify genes needed within the contest of breeding. Next generation sequencing (NGS) could be an approachable tool to discover genome-wide genetic markers and building saturated genetic map within reasonable cost and time. The cultivation of the species is relatively easy with diverse density according to the aim of the production. Actually, M. oleifera opens new dimension in field of agroforestry due its easily established, fast growing, diversify nature of its products, multiple benefits to people and their livestock and several other direct and indirect benefit to people worldwide. However, there are some constraints in cultivating $M$. oleifera which slow down the species adoption. With its easy propagation, its different parts with their various uses and its high morphological and genetic diversity, $M$. oleifera hold great potentials for in-depth investigation for the purpose of improvement and valorisation especially for food and nutrition security. There is need to increase the level of use and cultivation of the species through identification of factors which influence its adoption through its use and cultivation. Further studies are needed on breeding and genetic improvement of the species, on identification of ecotypes for industrial value with higher percentage of seed oil, proteins, medicine and wide adaptability to agro-climate. Finally, there is a very scanty scientific information on the 
potential of the species to mitigate effects climate change including food insecurity.

\section{ACKNOWLEDGEMENT}

This work was supported by a National Doctoral Scholarship of the Government of the Republic of Benin provided to the first author.

\section{REFERENCES}

Abdul, D.A.S. 2007. Economic importance of Moringa oleifera in Tafa local government area of Niger State. NDE Project. Federal College of Forestry Mechanization, Kaduna, Nigeria.

Abe, R. and Ohtani, K. 2013. An ethnobotanical study of medicinal plants and traditional therapies on Batan Island, the Philippines. Journal of Ethnopharmacology 145:554-565.

Abubakar, B.Y., Wusirika, R., MuA'zu, S., Khan, A.U. and Adamu, A.K. 2011. Detection of genetic variability using random amplified polymorphic DNA markers in some accessions of Moringa oleifera Lam. from northern Nigeria. International Journal of Botany 7:237-242.

Adebayo, A.G., Akintoye, H.A., Olufolaji, A.O., Aina, O.O., Olatunji, M.T. and Shokalu, A.O. 2011. Assessment of organic amendments on vegetative development and nutrient uptake of Moringa oleifera lam in the nursery. Asian Journal of Plant Sciences 10:74-79.

Agoyi, E.E., Assogbadjo, A.E., Gouwakinnou, G., Okou, F.A.Y. and Sinsin, B. 2014. Ethnobotanical assessment of Moringa oleifera in the Southern Benin (West Africa). Ethnobotany Research and Applications 12:551-560.

Agoyi, E.E., Padonou, E.A., Amoussa, W., Assogbadjo, A.E., Glèlè Kakaï, R. and Sinsin, B. 2015. Morphological variation, cultivation techniques and management practices of Moringa oleifera in Southern
Benin (West Africa). International Journal of Agronomy and Agriculture Research 6(3):97-105.

Animashaun, J. 2013. Prospects of agriculture enterprise for sustainable economic development: Success story of University of Ilorin moringa value-addition activities. In: Proceedings of the 4th International Conference of the African Association of Agricultural Economists, Hammamet, Tunisia, 22-25 September 2013.

Animashaun, J.O. and Toye, A.A. 2013. Feasibility analysis of leaf-based Moringa oleifera plantation in the Nigerian Guinea Savannah: Case study of University of Ilorin moringa plantation. Agrosearch 13(3):218231.

Ansari, M.M. and Kumar, S.D. 2012. Fortification of Food and Beverages with Phytonutrients. Food and Public Health 2(6):241-253. doi: 10.5923/j.fph.2012 0206.09 .

Anwar, F., Latif, S., Ashraf, M. and Gilani, A.H. 2007. Moringa oleifera: A food plant with multiple medicinal uses. Phytotherapy Research 21:17-25.

Arora, R.K. 1987. Ethnobotany and its role in domestication and conservation of native plant genetic resources. In: Jain, S.K. (Ed.). Manual of Ethnobotany. Scientific Publishers, Jodhpur, India. pp. 94-102.

Avakoudjo, J., Kindomihou, V., Akponikpè, P.I., Thiombiano, A. and Sinsin, B. 2013. Essences végétales et techniques de restauration des zones d'érosion (dongas) du Parc W et de sa périphérie à Karimama (Nord-Bénin). Journal of Applied Biosciences 69: 5487-5495.

Ayerza, R. 2011. Seed yield components, oil content, and fatty acid composition of two cultivars of Moringa (Moringa oleifera Lam.) growing in the Arid Chaco of Argentina. Industrial Crops and Products 33:389-394.

Azeez, F.A., Nosiru, M.O., Clement, N.A., Awodele, D.A., Ojo, D. and Arabomen, O. 2013. Importance of Moringa oleifera tree 
to human livelihood: a case study of Isokan local government area in Osun State. Elixir Agriculture 55:12959-12963.

Bhargava, N. 1981. Plants in folk life and folklore in Andaman and Nicobar Islands. In: Jain, S.K. (Ed.). Glimpses of Indian ethonobotany. Oxford \& IBH Publishing Co., New Delhi, India. pp. 330-344.

Biswas, A.K., Hoque, T.S. and Abedin, M.A. 2016. Effects of moringa leaf extract on growth and yield of maize. Progressive Agriculture 27(2): 136-143.

Bosch, C.H. 2004. Moringa oleifera Lam. In: Plant Resources of Tropical Africa, Volume 2: Vegetables; Grubben, G.J.H., Denton, O.A., Eds.; Backhuys Publishers: Kerkwerve, The Netherlands. pp. 392395.

Brunelli, D., Tavecchio, M. and Falcioni. C. 2010. The isothiocyanate produced from glucomoringin inhibits NF-kB and reduces myeloma growth in nude mice in vivo. Biochemical Pharmacology 79:1141-1148.

Centre for Jatropha Promotion and Biodiesel (CJP). 2014. Retrieved from: www. jatrophaworld.org/global moringa meet 81.html

Da Silva, A.V.C., dos Santos, A.R.F., Lédo, A.D.S., Feitosa, R.B., Almeida, C.S., da Silva, G.M. and Rangel, M.S.A. 2012. Moringa genetic diversity from germplasm bank using RAPD markers. Tropical and Subtropical Agroecology 15:31-39.

Da Silva, J.P.V., Serra, T.M., Gossmann, M., Wolf, C.R., Meneghetti, M.R. and Meneghetti, S.M.P. 2010. Moringa oleifera oil: Studies of characterization and biodiesel production. Biomass and Bioenergy 34:1527-1530.

Davey, J.W., Hohenlohe, P.A., Etter, P.D., Boone, J.Q., Catchen, J.M. and Blaxter, M.L. 2011. Genome-wide genetic marker discovery and genotyping using nextgeneration sequencing. Nature Review Genetics 12:499-510.

Dillard, C.J. and German, J.B. 2000. Review Phytochemicals: nutraceuticals and human health. Journal of the Science of Food and Agriculture 80:1744-1746.

DuPuy, D.J. 1993. Flora of Australia Volume 50: Oceanic Islands 2. Australian Government Publishing Service (AGPS), Canberra, ACT, Australia.

Ebert, A.W. 2014. Potential of underutilised traditional vegetables and legume crops to contribute to food and nutritional security, income and more sustainable production systems. Sustainability 6:319-335.

Fahey, J.W. 2005. Moringa oleifera: A review of the medical evidence for its nutritional, therapeutic, and prophylactic properties. Part 1. Trees for Life Journal: A forum on beneficial trees and plants 1:5. <http:// www.tfljournal.org>

Fahey, J.W., Zalcmann, A.T. and Talalay, P. 2001. The chemical diversity and distribution of glucosinolates and isothiocyanates among plants. Phytochemistry 56:5-51.

Ferrao, A.M.B. and Ferrao, J.K. 1970. Fatty acids of Moringa oil. Agronomia Angolana 8:3-16.

Foidl, N., Makkar, H.P.S. and Becker, K. 2001. The potential of Moringa oleifera for agricultural and industrial uses. In: Proceedings of the International Workshop "What Development Potential for Moringa Products?" Dar-es-Salaam, Tanzania. pp. 47-67.

Fuglie, L.J. 1999. The Miracle Tree: Moringa oleifera, Natural Nutrition for the Tropics. Church World Service, Dakar, Senegal. 68pp.

Gadzirayi, C.T., Kubiku, F.N.M., Mupangwa, J.F., Mujuru, L. and Chikuvire, T.J. 2013. The effect of plant spacing and cutting interval on growth of Moringa oleifera. Journal of Agriculture Sciences and Applications 2:131-136.

Gamatie, M. 2001. Moringa oleifera management systems in the Niger valley: The case of Sarandoarea. www.moringa news.org/actes/gamatie en.doc 
Ganesan, S.K., Singh, R., Choudhury, D.R., Bharadwaj, J., Gupta, V. and Singode, A. 2014. Genetic diversity and population structure study of drumstick (Moringa oleifera Lam.) using morphological and SSR markers. Industrial Crops and Products 60:316-325.

Hancock, I.R. and Henderson, C.P. 1988. Flora of the Solomon Islands. Research Bulletin No. 7. Ministry of Agriculture and Lands, Honiara, Solomon Islands.

Haq, S.U., Jain, R., Sharma, M., Kachhwaha, S. and Kothari, S.L. 2014. Identification and characterization of microsatellites in expressed sequence tags and their cross transferability in different plants. International Journal of Genomics 2014:863-948.

Hernandez, O.L., Tomes, A.V., Gonzalez, D.T., Cabrera, I.P., Pino, I.Y. and Gort D.D.C.G. 2015. Calculation of carbon sequestration and soil fauna associated with Moringa oleifera Lam. in living fences. Centro Agricola 42(1):75-81.

Jahn, S.A.A. 1996. On the introduction of a tropical multipurpose tree to China traditional and potential utilisation of Moringa oleifera Lamark. Senckenbergiana Biologica 75(1-2):243254.

Jain, S.K. 1981. Observations on ethnobotany of the tribals of Central India. In: Jain, S.K. (Ed.). Glimpses of Indian ethonobotany. Oxford and IBH Publishing Co., New Delhi, India. pp. 193-198.

Kasolo, J.N., Bimenya, G.S. and Ojok, L. 2010. Phytochemicals and uses of Moringa oleifera leaves in Ugandan rural communities. Journal of Medicinal Plants Research 4:753-757.

Kumar, Y., Thakur, T.K., Sahu, M.L. and Thakur, A. 2017. A multifunctional wonder tree: Moringa oleifera Lam open new dimensions in field of agroforestry in India. International Journal of Current Microbiology and Applied Sciences 6(8): 229-235.
Leone, A., Spada, A., Battezzati, A., Schiraldi, A., Aristil, J. and Bertoli, S. 2015. Cultivation, genetic, ethnopharmacology, phytochemistry and pharmacology of Moringa oleifera leaves: An Overview. International Journal of Molecular Sciences 16(6):12791-12835.

Liogier, H.A. and Martorell, L.F. 2000. Flora of Puerto Rico and Adjacent Islands: A systematic synopsis. 2nd Edition. Editorial de la Universidad de Puerto Rico, San Juan, Puerto Rico.

Lu, L. and Olson, M. 2001. Moringaceae. In: Flora of China, Volume 8: Brassicaceae through Saxifragaceae. Wu, Z-Y.and Raven, P. (Eds.). Missouri Botanical Garden Press, St. Louis, Missouri, USA.

Madi, O.P., Bourou, S. and Woin, N. 2012. Utilisations et importances socioéconomiques du Moringa oleifera Lam. en zone de savanes d'Afrique Centrale. Cas de la ville de Maroua au Nord-Cameroun. Journal of Applied Biosciences 60:44214432.

Mgendi, M., Manoko, M. and Nyomora, A. 2010. Genetic diversity between cultivated and non-cultivated Moringa oleifera Lam. provenances assessed by RAPD markers. Journal of Cellular and Molecular Biology 8:95-102.

Mgendi, M.G., Nyomora, A.M. and Manoko, M.K. 2011. Using morphological markers to assess variations between and within cultivated and non-cultivated provenances of Moringa oleifera Lam. in Tanzania. Journal of Life Sciences 5:387-392.

Morton, J.F. 1991. The Horseradish tree, Moringa pterygosperma (Moringaceae)-A Boon to arid lands? Economic Botany 45:318-333.

Mridha, M.A.U. 2015. Prospects of Moringa cultivation in Saudi Arabia. Journal of Applied Environmental and Biological Sciences 5(3):39-46.

Muluvi, G.M., Sprent, J.I., Soranzo, N., Provan, J., Odee, D., Folkard, G., McNicol, J.W. and Powell, W. 1999. 
Amplified fragment length polymorphism (AFLP) analysis of genetic variation in Moringa oleifera Lam. Molecular Ecology 8:463-470.

Navie, S. and Csurhes, S. 2010. Weed risk assessment: Horseradish tree, Moringa oleifera. Biosecurity Queensland, Department of Employment, Economic Development and Innovation, Queensland Government. 26pp.

Newton, A.K., Timpo, G.M., Ellis, W.O. and Bennett, R.N. 2006. Effect of spacing and harvest frequency on the growth and leaf yield of Moringa (Moringa oleifera Lam), a leafy vegetable crop. In: Proceedings on Moringa and Other Highly Nutritious Plant Resources: Strategies, Standards and Markets for a Better Impact on Nutrition in Africa. Accra, Ghana.

Noulèkoun, F., Lamers, J.P.A., Naab, J. and Khamzina, A. 2017. Shoot and root responses of woody species to silvicultural management for afforestation of degraded croplands in the Sudano-Sahelian zone of Benin. Forest Ecology and Management 385: 254-263.

Nouman, W., Basra, S.M.A., Siddiqui, M.T., Yasmeen, A., Gull, T. and Alcayde, M.A.C. 2014. Potential of Moringa oleifera L. as livestock fodder crop: a review. Turkish Journal of Agriculture and Forestry 38:114.

Nouman, W., Siddiqui, M.T., Basra, S.M.A., Farooq, H., Zubair, M. and Gull, T. 2013. Biomass production and nutritional quality of Moringa oleifera as a field crop. Turkish Journal of Agriculture and Forestry 37:410-419.

Nouman, W., Siddiqui, M.T., Basra, S.M.A., Khan, R.A., Olson, M.E. and Munir, H. 2012. Response of Moringa oleifera to saline conditions. International Journal of Agriculture and Biology 14: 757-762.

Ohri, D. and Kumar, A. 1986. Nuclear DNA amounts in some tropical hardwoods. Caryologia 39:303-307.
Ojiako, F.O., Adikuru, N.C. and Emenyonu, C.A. 2011. Critical issues in investment, production and marketing of Moringa oleifera as an industrial agricultural raw material in Nigeria. Journal of Agriculture Research and Development 10:39-56.

Okorocha, A.E., Folawiyo, M.A., Omabe, M., Omabe, K., Uzor, S., Uche, J.E., Wadioni, A., Ugwu, J.O. and Onwe, P.E. 2015. The Wonder Plant: Moringa oleifera. Journal of Environmental Science, Toxicology and Food Technology 9(10):39-47. DOI: 10.9790/2402-091023947.

Olson, M.E. 2002. Combining data from DNA sequences and morphology for a phylogeny of Moringaceae (Brassicales). Systematic Botany 27:55-73.

Oyeyinka, A.T. and Oyeyinka, S.A. 2016. Moringa oleifera as a food fortiûcant: Recent trends and prospects. Journal of the Saudi Society of Agricultural Sciences (in press). http://dx.doi.org/10.1016/ j.jssas.2016.02.002.

Pacific Island Ecosystems at Risk (PIER). 2007. Moringa oleifera Lam., Moringaceae. PIER: Plant threats to Pacific ecosystems. <http://www.hear.org/pier/ species/moringa_oleifera. $h t m>$. Institute of Pacific Islands Forestry, US Forest Service Padulosi, S., Heywood, V., Hunter, D. and Jarvis, A. 2011. Underutilized species and climate change: current status and outlook. In: Yadav, S.S., Redden, R.J., Hatfield, J.L., Lotze-Campen, H. and Hall, A.E. (Eds.). Crop adaptation to climate change, $1^{\text {st }}$ edn. Wiley, New York, USA. pp. 507-521.

Palada, M.C. 1996. Moringa (Moringa oleifera Lam.): A versatile tree crop with horticultural potential in the subtropical United States. HortScience 31:794-797.

Palada, M.C. and Chang, L.C. 2003. Suggested Cultural Practices for Moringa. International Cooperators Guide". AVRDC Publication Number 03-545:1-5.

Paliwal, R. and Sharma, V. 2011. A review on horse radish tree (Moringa oleifera): A multipurpose tree with high economic and 
commercial importance. Asian Journal of Biotechnology 3:317-328.

Paliwal, R., Sharma, V., Pracheta, Sharma, S., Yadav, S. and Sharma, S. 2011. Antinephrotoxic effect of administration of Moringa oleifera Lam in amelioration of DMBA-induced renal carcinogenesis in Swiss albino mice. Biology and Medicine 3(2):27-35.

Pamok, S., Saenphet, S., Vinitketkumnuen, V. and Saenphet, K. 2011. Antiproliferative effect of Moringa oleifera Lam. and Pseuderanthemum palatiferum (Nees) Radlk extracts on the colon cancer cells. Journal of Medicine Plant Research 6:139145.

Pandey, A., Pradheep, K., Gupta, R., Nayar, E.R. and Bhandari, D.C. 2011. 'Drumstick tree' (Moringa oleifera Lam.): A multipurpose potential species in India. Genetic Resources and Crop Evolution 58:456-460.

Popoola, J., Oluyisola, B. and Obembe, O. 2014. Genetic diversity in Moringa oleifera from Nigeria using fruit morpho-metric characters and random amplified polymorphic DNA (RAPD) markers. Covenant Journal of Physical and Life Sciences 1:43-60.

Popoola, J.O. and Obembe, O.O. 2013. Local knowledge, use pattern and geographical distribution of Moringa oleifera Lam. (Moringaceae) in Nigeria. Journal of Ethnopharmacology 150:682-691.

Potadar, V.R. and Patil, S.S. 2017. Potential of carbon sequestration and storage by trees in and around B.A.M. University campus of Aurangabad city in Maharashtra, India. International Journal of Scientific Development and Research 2(1): 28-33.

Proyecto Biomasa. 1996. Internal Report, UNI Managua.

Raja, S., Bagle, B.G. and More, T.A. 2013. Drumstick (Moringa oleifera Lamk.) improvement for semiarid and arid ecosystem: Analysis of environmental stability for yield. Journal of Plant Breeding Crop Science 5:164-170.
Ramachandran, C., Peter, K.V. and Gopalakrishnan, P.K. 1980. Drumstick (Moringa oleifera): A multipurpose Indian vegetable. Economic Botany 34:276-283.

Rufai, S., Hanafi, M.M., Rafii, M.Y., Ahmad, S., Arolu, I.W. and Ferdous, J. 2013. Genetic dissection of new genotypes of drumstick tree (Moringa oleifera Lam.) using random amplified polymorphic DNA marker. BioMed Research International 2013:1-6.

Saini, R.K., Saad, K.R., Ravishankar, G.A., Giridhar, P. and Shetty, N.P. 2013. Genetic diversity of commercially grown Moringa oleifera Lam. cultivars from India by RAPD, ISSR and cytochrome P450-based markers. Plant Systematics and Evolution 299:1205-1213.

Saint Sauveur, A. 2001. Moringa exploitation in the world: State of knowledge and challenges. Dar es Salaam. Tanzania. www.moringanews.org/actes/saintsauveur en.doc

Samant, S.S. and Dhar, U. 1997. Diversity, endemism and economic potential of wild edible plants of Indian Himalaya. International Journal of Sustainable Development and World Ecology 4(3):179191. doi:10.1080/13504509709469953.

Sawian, J.T., Jeeva, S., Lyndem, F.G., Mishra, B.P. and Laloo, R.C. 2007. Wild edible plants of Meghalaya, North Eastern India. Natural Product Radiance 6(5):410-426.

Shahzad, U., Khan, M.A., Jaskani, M.J., Khan, I.A. and Korban, S.S. 2013. Genetic diversity and population structure of Moringa oleifera. Conservation Genetics 14:1161-1172.

Sharma, V., Paliwal, R., Sharma, P., Sharma, S. 2011. Phytochemical analysis and evaluation of antioxidant activities of hydroethanolic extract of Moringa oleifera Lam. Pods. Journal of Pharmacy Research 4:554-557.

Shiriki, D., Igyor, M.A. and Gernah, D.I. 2015. Nutritional evaluation of complementary food formulations from maize, soybean and peanut fortified with Moringa oleifera 
leaf powder. Food and Nutrition Sciences 6:494-500.

Siddhuraju, P. and Becker, K. 2003. Antioxidant properties of various solvent extracts of total phenolic constituents from three different agroclimatic origins of drumstick tree (Moringa oleifera Lam.) leaves. Journal of Agriculture and Food Chemistry 51:2144-2150.

Sivasankari, B., Anandharaj, M. and Gunasekaran, P. 2014. An ethnobotanical study of indigenous knowledge on medicinal plants used by the village peoples of Thoppampatti, Dindigul district, Tamilnadu, India. Journal of Ethnopharmacology 153:408-423.

Smallholder Farmers Alliance (SFA). 2015. Moringa: Export Market Potential for Smallholder Farmers in Haiti. 71pp.

Suarez, M., Entenza, J.M., Doerries, C., Meyer, E., Bourquin, L., Sutherland, J., Marison, I., Moreillon, P. and Mermod, N. 2003. Expression of a plant-derived peptide harboring water-cleaning and antimicrobial activities. Biotechnology and Bioengineering 81:13-20. doi:10.1002/ bit.10550.

Tabbo, A.M. and Amadou, Z. 2017. Assessing newly introduced climate change adaptation strategy packages among rural households: Evidence from Kaou local government area, Tahoua State, Niger Republic. Jàmbá: Journal of Disaster Risk Studies 9(1): a383. https://doi.org/10.4102/jamba.v9i1. $\underline{383}$.

Tiwari, J.K., Ballabha, R. and Tiwari, P. 2010. Some promising wild edible plants of Srinagar and adjacent area in Alaknanda valley of Garhwal Himalaya, India. Journal of American Science 6(4):12-21.

Torimiro, D.O., Odeyinka, S.M., Okorie, V.O. and Akinsuyi, M.A. 2009. Gender analysis of socio-cultural perception of Moringa oleifera amongst farmers in Southwestern Nigeria. Journal of International Women Studies 10(4):188-202.

Ulloa, M. 2005. Molecular markers learning modules: using molecular marker technology in studies on plant genetic diversity. Crop Science 45: 2676-2677.

Verdcourt, B. 1985. A synopsis of the Moringaceae. Kew Bulletin 40:1-23.

Villafuerte, L.R. and Villafurte-Abonal, L. 2009. Data taken from the Forestry Agency of Japan in Moringa Malunggay Phillippines, Apples of Gold Publishing, Singapore, Pg 240.

Vishnu, M. 1981. Wild plants in Indian folk life. In: Jain SK (ed) Glimpses of Indian ethonobotany. Oxford \& IBH Publishing Co., New Delhi, pp 37-58.

World Agroforestry Centre (ICRAF). 2001. Agroforestree (AFT) Database. The ICRAF Agroforestry Tree Database. <http:// www.icraf.cgiar.org/Sites/TreeDBS/ aft.asp $>$. World Agroforestry Centre (ICRAF), Nairobi, Kenya.

Wu, J.C., Yang, J., Gu, Z.J. and Zhang, Y.P. 2010. Isolation and characterization of twenty polymorphic microsatellite loci for Moringa oleifera (Moringaceae). HortScience 45: 690-692

Yabesh, J.E., Prabhu, S. and Vijayakumar, S. 2014. An ethnobotanical study of medicinal plants used by traditional healers in silent valley of Kerala, India. Journal of Ethnopharmacology 154:774-789.

Zaku, S.G., Emmanuel, S., Tukur, A.A. and Kabir, A. 2015. Moringa oleifera: An underutilized tree in Nigeria with amazing versatility: A review. African Journal of Food Science 9(9): 456-461. doi: 10.5897/ AJFS2015.1346. 